\title{
TEACHER COLLABORATION AND INVITATIONAL LEADERSHIP IN A SOUTH AFRICAN PRIMARY SCHOOL
}

Prof GM Steyn

Department of Educational Leadership and Management

University of South Africa, P O Box 392, Pretoria 0003. South Africa

\begin{abstract}
The focus on schools as communities of learning for teachers has prompted professionals to investigate the role of professional learning within a school context. This is an attempt to investigate the voice of the principal regarding the implementation of teacher collaboration in his or her school, and to determine how teacher collaboration is aligned with assumptions of invitational education. A qualitative method of inquiry was employed to illuminate the experiences of a particular primary school principal in his endeavours to create and maintain a collaborative learning environment among teachers in an inviting school in South Africa. Data were analysed using the four assumptions of invitational education, namely, respect, trust, optimism and intentionality. From the findings it was clear that the implementation of teacher collaboration in the school was aligned with the four assumptions of invitational education. This study provides an appropriate basis for developing such a collaborative teacher community, thus improving teacher and student learning. However, since school contexts have a powerful effect on teacher collaboration, it is important to contextualise teacher collaboration according to schools' particular needs and challenges.
\end{abstract}

Key words: invitational education, school leadership, teacher collaboration, professional development

\section{Introduction}

Emerging models for continuing professional development of teachers involve teachers in collaborative activities to enhance their professional development, and correspondingly, bring about meaningful changes in teaching practice and improved student performance (Brouwer, 2011, p. 7; Darling-Hammond, Wei, Andree, Richardson, \& Orphanos, 2009, p. 5; Ertesvåg, 2011, p. 1; Goddard, Goddard \& Tschannen-Moran, 2008, p. 878; Lockhorst, Van der Pol \& Admiraal, 2008, p. 253; Nehring \& Fitzsimons, 2011, p. 516). In this regard Williams (2010, p. 139) states 'Models of professional learning that build teacher collaboration are useful in closing the achievement gap as they build structures that break down isolation and encourage 
teachers to work together, rather than competitively, toward commonly established goals for student learning'. In line with this view, Chappuis, Chappuis and Stiggins (2009, p. 57) and Printy (2010, p. 125) advocate a learning-team model of professional development to enhance on-going, deeper teacher-directed learning that removes teacher isolation, which is a barrier for effective professional development and quality teaching. However, this means that professional learning can only be understood when understanding the role that the school plays in teachers' learning (Pedder \& Opfer, 2011, p. 196).

The focus on schools as communities of teacher learning and collaborative workplaces has prompted scholars to investigate the role of professional learning in the school context (Williams, 2010, p. 3). Recent studies, however, show the complex nature of professional learning among teachers (Printy, 2010, p. 125; Sigurðardóttir, 2010, p. 397). Christianakis (2010, p. 110), therefore, proposes that studies in collaborative learning are required to shape educational policies and also to assist in navigating the complexity of theory and practice. Furthermore, Louis, Dretzke and Walhstrom (2010, p. 331) show that principals and teachers need to acknowledge and act on the increased importance of collaborative learning for the sake of improved teaching practices. It is not only teachers who need to work together, but school leaders should also play an important role in this process. Principals exert greater impact on teachers when they jointly work with them on aspects that influence their classroom practice (Printy, 2010, p. 113). It involves their active participation in teachers' professional development or by changing the authority structures in the school to allow shared leadership (Louis et al, 2010, p. 332).

Moreover, on-going teacher collaboration in teams has become more significant in dealing with educational reforms and the increasing complexity of teachers' responsibilities (Brouwer, 2011, p. 21; Maistry, 2008, p. 137). In line with international calls for improving the quality of teachers, recent education policy developments in South Africa have called for increased attention to continuous professional development of teachers to improve the quality of education in South Africa (The Department of Education, 2011, pp. 73, 75; Maistry, 2008, p.119). The teacher summit in South Africa suggested that visionary leaders are required and that principals need to play a key role in teachers' professional development (Department of Education, 2011, p. 90).

While studies explain the processes to create collaborative structures in schools (Katz \& Earl, 2010, p. 27, 28; Maistry, 2008, p. 137), few studies focused on the role of principals to initiate 
and develop professional learning communities in their schools (Cranston, 2009, p. 2; Gaspar, 2010, p. 34). Furthermore, no studies were done to determine how the design of collaborative structures in a school is aligned with invitational leadership. Invitational education, on which invitational leadership is based, is a theory of practice that is designed to create, sustain and promote human environments that cordially invite people to realise their human potential (Purkey \& Novak, 2008, p. vii). It is a 'fresh paradigm' that views leadership as a power for positive social change in which leaders present others with opportunities to participate in creating something of mutual benefit and invite them to higher levels of professional functioning (Purkey \& Siegel, 2003, p. 6). The study, therefore, attempted to investigate the voice of a principal as regards the implementation of teacher collaboration in his or her school, and to determine how the implementation of teacher collaboration is aligned with invitational leadership.

This study is considered to be significant since it has the potential to benefit schools and contribute to the body of knowledge on school management (Blacklock, 2009, p. 20) and invitational education. It will assist in providing a better understanding of an inviting, collaborative organizational structure in a school that may affect changes in the classroom, and show how this structure is aligned with the assumptions of invitational education. Looking at the experiences of a principal who designed the teacher collaborative structure in the school was a good start for understanding teacher collaboration and how it aligns with invitational education. This study, which was one of a number of studies of a new principal at a particular primary school (Steyn, 2013a; 2013b), focused in particular on the principal's role in promoting teacher collaboration.

In the previous studies conducted at this school, the principal revealed strong leadership behaviours, a sense of shared responsibility for teachers' and students' learning, a strong commitment to the professional development of teachers and strong parent support for instructional practice. The particular research question that emerged in the study was to establish how the principal perceived the introduction and maintenance of teacher collaboration in the primary school and how teacher collaboration was aligned to the assumptions of invitational education.

\section{Conceptual framework}


This study used two lenses to interpret the collaboration of teachers in the primary school. It relied on current studies on professional, collaborative learning of teachers and on the theory and practice of invitational education.

Although scholars differ in the definition of a professional learning community, researchers agree that it is a team of professionals purposefully and collectively sharing their practice in an collaborative, on-going, learning-oriented reflective and growth-enhancing way to facilitate both teachers' and students' learning (Blacklock, 2009, p. 14; Greer, 2012, p. 8; Piccardi, 2005, p. 12; Stoll, Bolam, Mcmahon, Wallace \& Thomas, 2006, p. 223). The focus is not only on the individual teachers' professional learning, but also on collaborative professional learning within a particular school community context in which a group of teachers work together, share a goal, determine their progress and make the necessary corrections to achieve this common goal (McLaughlin \& Talbert, 2010, p. 35; Stoll et al, 2006, p. 225).

In line with this view, Pedder and Opfer (2011, p. 741) believe that teacher learning occurs primarily as the outcome of the interaction of teacher's collective beliefs and practices, which has a major impact on their individual learning. It implies that teacher collaboration validates the individual practices of teachers, while also encouraging a collective and collegial focus on student learning goals (Williams, 2010, p. 139). When teachers collaborate, they share experiences, skills and knowledge while more meaningful professional learning occurs that can enhance their instructional practice, and ultimately influence student performance (Darling-Hammond et al, 2009, p. 11; Goddard, Goddard \& TschannenMoran, 2008, p. 891; Nelson, Deuel, Slavit \& Kennedy, 2010, p. 178).

Traditionally teachers worked in isolation with little professional dialogue and discussion (Chappuis et al, 2009, p. 57; Ertesvåg, 2011, p. 1; Nehring \& Fitzsimons, 2011, p. 526; Williams, 2010, p. 18). Currently, to meet student needs, this tradition of solo-practice has to change to a collaborative practice where teachers continuously engage in teams to develop their knowledge and skills (Fulton \& Britton, 2011, p. 5). Professional learning communities, therefore, require certain structural circumstances that, inter alia, encourage shared leadership, create a shared vision and shared professional practice, and provide professional development that focuses on improved student learning (Blacklock, 2009, p. 10; Stoll et al, 2006, p. 225). 
In essence, the professional learning model of Pedder and Opfer (2011, p. 743) suggests that there are shared learning practices and beliefs in schools that constitute a school's organizational orientation to teacher learning. These practices and beliefs impact the particular learning activities in which teachers participate collaboratively and also the success of making the necessary changes in their teaching practice as a result of their professional learning (Pedder \& Opfer, 2011, p. 743). Sigurðardóttir (2010, p. 407) states that interdependency is a requirement for teachers' collaborative learning.

A professional learning community is not considered as a model, but rather a process or an approach with a set of characteristics that serves as a lens to examine teacher collaboration (The Centre for Comprehensive School Reform and Improvement, 2009a, p. 1). Little (1982, p. 331) identifies the following four different kinds of collaborative activities that impact teachers' collaborative learning and are characteristic of more successful schools:

(a) Teachers participate in frequent, continuous and increasingly concrete and accurate conversations about their teaching practice.

(b) Teachers are often observed and receive valuable criticism about their teaching. (c) Teachers design, plan, study, prepare and evaluate teaching materials together.

(d) Teachers act as teachers for others in the practice of teaching.

Her views coincide with Vescio, Ross and Adam's four characteristics of teacher learning communities (2006, p. 10-12), namely, the following:

(a) Successful collaboration encourages the sharing of teaching experiences, beliefs, views, reflection and the taking of risks to make the necessary changes.

(b) It focuses on improving students' performance.

(c) Teachers have the authority and ability to influence the processes of the learning teams.

(d) Teacher learning occurs continuously for teachers to learn and improve their practice.

The approaches of Little (1982) and Vescio et al (2006) also share features with Katz and Earl's notion of learning community (2010). According to Katz and Earl (2010, p. 29-32), there are six such features in a teacher learning community: 
(a) It has a clear focus and purpose that is based on proof that collaboration can have a meaningful impact on both teacher practices and student performance, which should be adapted for the particular school considering its context, needs and history.

(b) Through relationships, teachers create a sense of shared responsibility, common language and create the necessary channels for communication that is based on trust (see also Hargreaves, 2007, p. 187; Supovitz, Sirinides \& May, 2010, p. 35).

(c) Collaboration includes more than mere relationships, since it refers to intensive interaction in which teachers are engaged so that their practices and beliefs can be investigated and debated.

(d) Inquiry, which refers to professional reflection as well as systematic analysis of a particular situation, involves key activities for 'both individual and collective construction of meaning' (Katz \& Earl, 2010, p. 30).

(e) Shared leadership exists on many levels alongside formal leadership structures in schools.

(f) It is important to build support and capacity by creating conditions that are conducive to both individual and collective learning.

The different approaches to teacher collaboration imply that professional collaborative learning in schools needs to be carefully planned and organised in such a way that teachers are regularly engaged and that all students can benefit (Darling-Hammond et al, 2009, p. 3; Nehring \& Fitzsimons, 2011, p. 524). This means that teachers should be organised in teams, based on their grade level or content learning area (Darling-Hammond et al, 2009, p. 3). As teams, they take responsibility to use a cycle of continuous student improvement to identify learners' needs and the areas in which teachers require development to address learners' needs, and then to create the necessary learning experiences to address teachers' needs, to apply and reflect on new skills in the classroom and to repeat the improvement cycle with new goals (Department of Education, 2011, p. 75; The National Comprehensive Centre for Teacher Quality, 2011, p. 5).

The second lens that was used to analyse the findings is based on the theory and practice of invitational education (IE). This is essentially an ethical approach for creating and sustaining a welcoming learning environment for people in educational institutions for the sake of 
increased learning outcomes and professional growth (Shaw, Siegel \& Schoenlein, 2011, p. 4). IE identifies the following four assumptions about people, which also served as a guideline to interpret the findings (Schmidt, 2004, p. 27; Hunter \& Smith, 2007, p. 12; Shaw et al, 2011, p. 2): respect, trust, optimism and intentionality.

(a) Respect: People are able, valuable and capable of self-direction, and should be treated accordingly. Invitational leadership regards respect for people as the most important belief (Purkey \& Siegel, 2003, p. 7). It is the basic belief that people have inherent worth and selfdirecting power, and leaders who value respect will find ways to help role players in the school to succeed (Burns 2007, p. 51). Purkey and Siegel (2003, p. 8) succinctly state that respect is 'manifested in intellectual discourse and a willingness to express vigorous dissent while remaining open to the expressions of others'. Invitational leaders acknowledge that their success depends upon other people in the organization (Purkey \& Siegel, 2003, p. 8).

(b) Trust: Education is a cooperative, collaborative activity in which the process of working together is as important as the end product. Trust is an essential element that reveals a confidence in the integrity and abilities of others and themselves (Burns, 2007, p. 51) and, therefore, implies a commitment to the appreciation of the continuous development and growth of everybody involved in education. Trusting people means moving towards collaboration and giving up a sense of control. Trust in the ability and growth of people is best if it is lived and demonstrable. In essence, trust implies the interdependence of human beings (Novak \& Purkey, 2001, p. 13; Purkey \& Siegel, 2003, p. 13). Once leaders have established trust in their organizations, they have come a long way in ensuring success in those organizations (Purkey \& Siegel, 2003, p. 13). However, it means that both effort and ample time are required to develop and sustain a cooperative and collaborative stance in a school environment.

(c) Optimism: People possess relatively untapped potential in all areas of human development. In the midst of high standards and difficult challenges, optimism could be a 'dynamic element' in attaining success (Burns, 2007, p. 50). Invitational leaders accept this optimistic view of humans and their potential (Purkey \& Siegel, 2003, p. 15). Leaders demonstrate trust in people when people are allowed to take risks, to make mistakes and to learn from these mistakes. Moreover, optimistic leaders are more eager to change, even when facing challenging situations and 'immovable barriers' (Purkey \& Siegel, 2003, p. 18). 
(d) Intentionality: Human potential can best be realised by places, policies and programmes that are intentionally designed to invite human development, and by people who consistently seek to realise this potential in both themselves and others. 'Intentionality is at the very heart of Invitational Leadership (Purkey \& Siegel, 2003, p. 19). A commitment to work intentionally in developing a suitable school environment is characterised by both purpose and direction for the advantage of all role players in a school. Invitational leaders join followers in the development and design of appropriate places, policies, programmes and processes to attain their shared aims (Purkey \& Siegel, 2003, p. 21).

\section{Research methodology}

A qualitative method of inquiry was adopted for this study (Williams, 2010, p. 39), while the interpretative research paradigm that focuses on 'verstehen' formed the basis of the study (Johnson \& Christensen, 2012, p. 36). This study was intended to illuminate the experiences of a school principal in his endeavour to create and maintain a collaborative learning environment among teachers for the sake of their professional development and quality education in the school. Since the school received the Inviting School Award in 1993 under the leadership of the principal's predecessor, the invitational education lens was indispensable to determine in which way the new principal's efforts met the model of invitational leadership.

The descriptive, single case study investigated the status of the four assumptions of invitational education theory in the realization of a collaborative learning culture in the school. A case study is particularly valuable when studying educational innovations (Gaspar, 2010, p. 38). Since the new principal initiated the collaborative learning culture and was the driving force behind this approach, the data were collected through interviews with the principal in 2012 and 2013 (Greer, 2012, p. 46). These interviews focused on the creation of a teacher collaborative learning culture in the school and the role that the principal played in realizing it. All interviews were recorded and transcribed. The first three interviews were conducted in Afrikaans and translated into English considering the idiom of the language. It was by chance in the last interview that the researcher 'discovered' that the principal, who taught English at the school, was prepared to answer the interview questions in English. Member-checking was done to ensure that the interview findings were accurate.

Since the focus in the article was on teacher collaboration as observed through the lens of invitational leadership, the four principles were used as categories in the coding and analysis of data. These categories were contextualised by using in vivo coding to 'prioritize and honor the 
participant's voice' in the study (Saldaňa, 2009, p. 74). Ethical measures included the permission of the Department of Education in Gauteng and the University of South Africa to conduct the study at the school. The principal also gave his consent to participate voluntarily and to extend his involvement in the study.

\section{Findings}

\section{The school context}

The primary school is located in a middle class urban area with approximately 1750 students at the time of the study. The school exempted $10 \%$ of the students from paying school fees. In the primary school, the teacher collaboration structure became dominant in the second year after the new principal's appointment. The school's vision was focused on excellence, and aimed to develop the potential of every student, while its mission, inter alia, indicated the school's pursuit of academic excellence through maintaining quality professional development. To attain this goal the principal worked very hard to convince all role players to share the same vision. It implied that the school had to change its academic focus, which then became 'very strong'. The school profile showed homogeneity and stability of both teachers and students. The school's success in various fields earned a high reputation among neighbouring secondary schools and in the community. Many applications to enter the school were turned away annually, since the school could not cater for these growing numbers.

A number of studies were conducted previously at this school. These included sustaining an inviting culture in the school (Steyn, 2006; 2007), professional development of teachers (Steyn 2009; 2010) and dimensions of school leadership (Steyn, 2012a; 2012b). The principal who participated in the study took office at the beginning of 2010. Recent studies have focused on his professional and organizational socialization since he took office (Steyn, 2013a; 2013b). Already in his first months in office the principal perceived a 'laxity' of staff in the senior phase concerning academic development. He explained:

Mr A [the predecessor], the unbelievable man that he was, trusted staff ... and they abused his kindness .... Staff took chances and got away with it ... That was a crisis to me and we had to work very hard to change the attitude of staff regarding professional development and how staff felt about their academic work.

The improvement of academic performance was, therefore, a major concern of the principal during his first year in office. The principal was of the opinion that the school needed to ensure 
that everything ran smoothly if they strived to be a school of excellence. He considered himself a 'control freak' in making the necessary changes, because he wanted to provide 'a good service and nothing else'.

The next four sections use the set of four guiding principles of invitational leadership to show how the principal realised them in creating a collaborative learning environment for teachers.

\section{Respect: 'There are many teachers who think out of the box'}

Invitational leaders expect others and themselves to be able, valuable and responsible (Purkey \& Siegel, 2003, p. 8). It was clear from the principal that he abided by this principle by, inter alia, acknowledging the expertise of staff in the school. He stated:

Many teachers are masters in their subjects and they have many years of experience. Inexperienced teachers, however, require more training. Staff should never think that they have arrived ... people can easily get into a rut. That is why innovative thinking is so important .... There are many teachers who think out of the box.

Unlike other schools, the school's governing body appointed a second principal, who was financially supported by the governing body. The first principal was not threatened by having a second principal and rather praised this second principal for being a 'genius' in planning and developing infrastructures: 'Half of this school exists because of him.'

The principal provided opportunities for teachers to share their experiences and expertise. The teachers were also willing and felt empowered to share these experiences with other teachers by inviting them to observe their lessons. The principal stated: 'It is fantastic that they [teachers] have the freedom to do that and that they have the faith in themselves to do that ... I think you learn a lot by that.'

Apart from recognising teachers' abilities, the principal was also proud of his staff's performance. The school implemented the Curriculum Assessment Policy Statement (CAPS) training a year before it became compulsory and neighbouring schools admired the expertise of his staff. Moreover, the school's Mathematics teacher was appointed as the best cluster leader and also set the Mathematics paper for Grade 6. 'She is just exquisite'.

The principal's high regard for his staff and his humility in leading them can be illustrated by the following statement: 
To be brutally honest ... it is not because of me, it is because of them [staff members], I am a cog in that big machine, without which the machine won't be able to run ... [However] it is not one person ... no outcome has been reached because of me. I think the outcomes have been reached despite me ... it is a team effort.

Invitational education is an intentional approach that begins and also ends with people (Purkey \& Novak, 2008, p. 21). An invitational leader's unconditional respect for everybody and honouring diversity are crucial elements in creating and sustaining an inviting school culture (Purkey \& Siegel, 2003, p. 8). Bowen (2006, p. 55) states that respect for people means to consider people worthy of high regard, which was demonstrated by the principal in the study. Moreover, for this quality to filter through the whole school, it had to start with the principal, who modelled it as often as possible. However, as demonstrated in the study, the invitational leader is always aware that success depends on upon the contributions of others (Purkey \& Siegel, 2003, p. 9). Respect for the expertise of teachers and providing opportunities for them to share their expertise enhanced the creation of a collaborative school culture that is conducive to facilitating learning (Rhodes \& Houghton-Hill, 2000, p. 432). The principal focused on capitalising on teachers' expertise and knowledge and building teacher leadership for the sake of creating and also sustaining effective professional communities in the school (McLaughlin \& Talbert, 2007, p. 157; Raihani, 2009, p. 489). Once teachers collaborate they are in a position to complement one another's skills and knowledge, and thereby enhance their professional ability (Dymoke \& Harrison, 2006, p. 78; Lee, 2005, p. 45).

\section{Trust: 'Success in the classroom depends $100 \%$ on teacher collaboration'}

Trust is indispensable to invitational leadership since it acknowledges people's interdependence (Purkey \& Siegel, 2003, p. 2). However, the principal regarded it as his responsibility to create a collaborative learning environment and felt that he had a major role to play in making collaboration successful. Already during his first year in office he realised that teachers were 'very isolated' in their work. He elaborated:

We had little islands of excellence in the school, but there was no cohesion, it was my job (and still is) to make sure that there is cohesion and there can only be cohesion if everyone understands where we are going and why we are going there.

It implied that unless the principal bought into the collaborative system, it would not work. If he just sat in his office 'drinking coffee with guests', this could not happen. For successful collaboration the principal indicated that he himself was actively involved in teaching, 
marking students' work and planning lessons to have a clear understanding of the work teachers did and what they needed. However, getting the cooperation of staff to collaborate was a 'huge leap'. He believed that for many years teachers had kept their expertise to themselves. Teachers needed to share their intellectual property, share their knowledge and, according to the principal, 'stop the ridiculous competition' and seeing each other as opposition. It was the principal's role to teach them that and to monitor staff. He elaborated on this:

Teachers were mere islands and everybody was busy with his or her own grade. Now the Grade 2 teacher had to talk to the Grade 3 teacher ... Everybody began to realise that they are interdependent, but this was not easy ... Everything is about continuity and communication ... Change is difficult ... Many teachers cried crocodile tears ... and experienced the new system as critique against their system. One teacher even threatened to resign should I continue with the system.

The principal was pleased that most of the teachers were willing to listen and to see the bigger picture. For him it was, however, a feeling of 'adapt or die'. In the course of time the school began to focus on continuity and that was just 'amazing'. The principal added that teachers had to ensure that they were 'on the same boat' and that they knew where we were going; 'Only when they know why, and where the destination is, will they get to the how ... But they won't have the same goal unless they understand why.' Instituting the new collaborative system worked out much better than expected and the principal was very proud of the change. What fascinated the principal most was the feeling of 'brotherhood' that developed among staff as the result of collaboration.

In practice, teacher collaboration in the school meant that the staff gathered officially three times a week, the different phases met once a term to discuss a whole range of aspects, such as examinations, while grade groups and subject groups gathered formally once a week. There were 'very well qualified people' who were in charge of groups; in these groups 'we sit together and we pull together'. Staff also had informal daily discussions to ensure that they covered the same content and that they were 'at the same place' in their classes. The principal was of the opinion that there was no other way to ensure student success than through teacher collaboration. He stated:

Success in the classroom depends $100 \%$ on teacher collaboration. If there is no or little teacher collaboration, you miss the point ... We are driving an idea and an ideal, which is 
so fragile that if there is no continuity and collaboration you will not get to the final destination. You will pull in all different directions but you won't get where you are supposed to be ... I mean the individual child and if we don't collaborate, we fail them.

For teachers to work together, the principal indicated that there were obstacles to overcome. He referred to the 'many different personalities' of teachers and explained that they each came from 'a different point of view'. For him that was what the 'art' of collaboration amounted to. He said:

Differences of opinion and differences in personality, it could be a hindering factor, but it shouldn't be. Because if you believe in what you are doing, you will get past yourself and over yourself ... And you will buy into where we go.

Considering these differences among staff members it is, therefore, important that there should be trust among them to ensure collaboration. 'Trust in each other and trust in the process'. Trust of staff members to follow the principal who led collaboration was also very important. 'When they [teachers] trust you [the principal], even if they might not agree, they will go with you.'

The invitational education philosophy is built on the underlying interdependence of individuals in a complex ecosystem (Purkey \& Novak, 2008, p. 14). For effective invitational leaders, trust is crucial since they recognises the interdependence of human beings, which was confirmed in the study. It is viewed as a confidence in the abilities and responsibilities of other people (Purkey \& Siegel, 2003, p. 12). When trust exists, risk-taking is likely to occur, and once there is risk-taking, there is the likelihood of creativity and innovation in the organization (Purkey \& Siegel, 2003, p. 14).

The findings in the study are confirmed by literature on teacher collaboration. For teacher collaboration to function effectively, the role of the principal should change to become an instructional leader and distribute the school's leadership across the various team units and members in the school (McLaughlin \& Talbert, 2007, p. 157). Through professional relationships, teachers create a sense of shared responsibility, a common language, and they create the necessary channels for communication, which is based on trust (Katz \& Earl, 2010, p. 29, 30; Hargreaves, 2007, p. 187; Supovitz et al, 2010, p. 35). The principal stated that teachers began to care about each other's personal lives and their care was translated into trusting their colleagues professionally, which is critical for effective teacher collaboration 
(Fleming, 2007, p. 28). As also confirmed in this study, Hargreaves (2007, p. 187), Fulton and Britton (2011, p. 15), and Greer (2012, p. ii) believe that trust is the backbone of strong teacher collaboration, which takes effort and time to develop.

\section{Optimism: 'To become "a better teacher and, hopefully, a better person"',}

Inherent in this principle is an optimism and a commitment to the continuous growth and appreciation of everyone in the school (Purkey \& Novak, 2008, p. 14). People have a desire 'to be affirmed in their present worthwhile being summoned cordially to realise their potential' (Purkey \& Siegel, 2003, p. 15). Although the principal acknowledged the school had 'high quality teachers' for each subject, he was of the opinion that people should not 'stagnate' and needed to develop continuously in a systematic way to grow and to be empowered. He also encouraged teachers to arrange workshops for other schools. As an example, the school did not wait for the Department of Education to introduce Grade R teachers to the latest developments and, therefore, decided to take the lead and become the 'information source'. As a result they presented a Grade R conference, which was 'fantastic' with unbelievably positive feedback. The goal for the principal in developing teachers' potential was to help the teacher to become ' $\mathrm{a}$ better teacher and hopefully a better person'. He had a similar view for learners. At the yearend function for 2012, the principal reiterated that the focus of the school goes much further than the primary school and high school: 'We want every learner to obtain a degree and not only pass Grade 7 successfully. What we strive to do is to get learners to attend university'.

Already, in his first year, the principal succeeded in reducing the number of students in Maths classes to 15 for Grade 7. The system was extended to Grades 5 and 6 in the following years. The impact of the change was tremendous and he did not intend to 'brag' about it, but nevertheless felt very satisfied about its impact. Thirteen of the school's learners who went to a neighbouring secondary school obtained an average of above $80 \%$ for the entrance examination compared to the grade average of $40 \%$. He attributed this success to the smaller Maths classes and the stronger focus on academics.

According to invitational education, emphasising human potential does not imply a naïve belief that 'good things will occur automatically' (Purkey \& Novak, 2008, p. 14). A school that practises invitational education is committed to the continuous growth and appreciation of all individuals in the education process (Purkey \& Novak, 2008, p. 14). Invitational leaders do not see change as a threat, but rather as an important step in professional growth (Purkey \& Siegel, 2003, p. 15). 
As seen in the findings, the changed beliefs and practices influenced the academic focus of the school and resulted in a collective responsibility for and a stronger focus on academics (The Centre for Comprehensive School Reform and Improvement, 2009a, p. 1). In essence it means that although the development of individuals played a key role, team work extended the expertise of individual teachers when the pooled experience of individuals was used (Richardson 2009, p. 22; Williams 2010, p. 10). Once individual teachers were empowered to improve their own competency, teachers were encouraged to share their knowledge and skills with others as models for them to follow, even in other schools (Drago-Severson 2007, p. 99).

\section{Intentionality: 'Good enough, is not good enough for me. It should be excellent.'}

Of the four principles of invitational leadership, intentionality plays a key role since it gives all human activities both direction and purpose (Purkey \& Siegel, 2003, p. 19). It also means that teacher collaboration does not happen by accident. The principal stated that their school was serious about professional development of teachers, but that he also had to work hard on the attitude of staff regarding their own professional growth. He considered the quality of education as his responsibility. On this matter he made the following comment:

For me the problem is in the classroom, that is our core business, that is why we are here...

We are not here to be best pals for each other; we are here to work together and to do it well. I try to be a 'nice' guy, but that is somewhat difficult... Good enough, is not good enough for me. It should be excellent. For me it is about an attitude about quality.

The principal, in particular, considered teacher collaboration of 'paramount importance' for the professional development of teachers. He regarded it as his 'job and duty' to identify which structures or teams there should be, but acknowledged that it was 'difficult' to structure it properly 'because teacher collaboration works on different levels'. He was responsible for creating 'some of those structures which weren't necessarily there or just streamlining those which were here and getting everyone at the same place, so that we understand why it is important to have these structures.' The principal explained the challenge of implementing collaboration within the school:

Everyone kept their guard like this [the principal folded his hands in front of his chest]... we have had to come a long way, or go a long way in order to get people to share with one another and to reach out so that continuity can happen, but that collaboration is key in our school now and people are actually proud of sharing with other people. I love that. 
He elucidated that the collaboration of teachers had to be structured, that it had to be guided and monitored. If this was done properly, continuity was possible. As regards the different structures and opportunities for collaboration, the principal explained as follows:

We have grade meetings, where the grade leader leads them [teachers] and they share whatever works for them and they share the questions and they share the work charts and things that they have done ... [For example] In the foundation phase, teachers work in cycles... they [teachers] take one topic [in a cycle] and that becomes the centre of everything in all the different subjects and learning areas. One person in that grade works out the mathematics work charts, another does the English Language, yet another does Social Sciences, et cetera... They rotate this so that everyone gets a chance [to be responsible for a work chart] ... and then they work together... they all do exactly the same work and they learn from each other.

Apart from structuring team work, the principal also identified the appropriate time for teachers to collaborate as a 'huge obstacle' and said he had to be creative in allowing adequate time for team work. The principal indicated that a high level of collaborative learning required an appropriate time schedule that allowed the staff to meet regularly. He stated that the Department of Education expected twenty seven and a half hours of academic time each week. To be able to do that, without extending their school day to 15:00, the school discontinued registered class periods. The school had one assembly of 45 minutes on a Monday and a test period on a Thursday, so that classes could start at 07:30 on other days. The schools scheduled subject and other team meetings during the assembly period, during breaks or mostly after school. The principal described these meetings as a time for teachers to brainstorm and to share ideas about good teaching strategies that can be used in the classroom.

A number of changes occurred as the result of the focus on quality education and teacher collaboration. According to the principal, these changes included the following:

- As mentioned before, the academic focus in the school moved '180 degrees', which resulted in changes to the academic policy and structure. The school instituted scheduled tests weekly, and two scheduled examinations annually. Teachers' test and examination papers were monitored by the subject heads; 'everything was double checked' to ensure accuracy. The school was also in the Super 12 as far as academics was concerned. Homework for students was posted a week before the time on the website and teachers needed to be ready to do so. It helped parents and students to plan the school work 
accordingly. The stronger focus on academics made the principal 'very proud and satisfied'.

- The continuity between grades 'improved tremendously' as was mentioned before. Since the new collaboration structure was implemented, the different grades communicated with one another and the transition to the next grade was ' $80 \%$ less difficult' for students.

- The principal expanded the reward system where more children received academic recognition, not just the Top Ten only. As a result students became more dedicated to their academic work. Students were eligible for platinum, gold, silver and bronze medals; there were 175 students out of a possible 200 in the academic team.

- The school first appointed a Teacher of the Year in 2012. It was the second principal of the school, who was the project manager for the new Grade R Centre.

The principal's advice for schools that consider a move towards teacher collaboration was to 'begin small'. Staff first needed to share the vision for collaboration and they should buy into the ideal. Only once all people are in the 'same boat' can the principal begin to 'steer' them. The principal acknowledged the differing school contexts and, therefore, admitted that what worked in one school might not work in another since the dynamics and socio-economics might differ.

According to invitational leadership, intentionality means to act with an aim and purpose (Purkey \& Siegel, 2003, p. 20). Developing and maintaining clear and specific actions in the school enhanced the process of growth and development (Burns, 2007, p. 51). The findings confirm how the principal intentionally designed processes and introduced appropriate policies and structures to promote collaboration among staff members. This often meant that the principal had to introduce tough measures and would not be viewed as a 'nice' person. This is confirmed by Novak amd DiBiase (2006, p. 251), 'Nice people doing nice things is nice, but the inviting perspective needs to go beyond niceness to sustain inviting schools in not-so-nice times'.

The findings in this study are supported by those in other studies. It is the responsibility of the principal to lead teachers to learn and work with a common purpose by creating effective collaborative structures for them in the school (Fleming, 2007, p. 24), as was also shown in this study. Intentional efforts to create conducive conditions such as appropriate collaborative structures to reduce teacher isolation, a scheduled time to meet, norms of behaviour, 
availability of resources and appropriate communication structures are required (Fulton \& Britton, 2011, p. 14; Greer, 2012, p. 8; Williams, 2010, p. 18), which were indicated in the study. The principal also needed to be creative to adapt the school programme and arrange appropriate time for team and staff meetings to occur (DuFour \& Marzano, 2007, p. 66; Fleming, 2007, p. 26). Moreover, as in the case with the studies of Blacklock (2009, p. $223,224)$ and McLaughlin and Talbert (2007, p. 158), the principal instituted a high level of collective learning, which allowed the staff to meet at grade level team meetings, between grade levels and in subject areas. The findings also supported the notion that teacher collaboration is not a single event, because it develops over an extended period of time (Fulton \& Britton, 2010, p. 36; Fulton \& Britton, 2011, p. 7). This also applies to continuity, since it takes time for teachers to develop trusting relationships and more time to build norms, a common language and certain protocols that work for a team of teachers (Fulton \& Britton, 2010, p. 47; Fulton \& Britton, 2011, p. 15).

Figure 1 provides a brief overview of the study findings. The way in which the principal led the teacher collaboration practices in the school, revealed that he possessed particular invitational leadership qualities. 


\section{TEACHER COLLABORATION}

- The principal played a key role in initiating and maintaining teacher collaboration.

- Respect for the worth and expertise of staff enhanced the building of teacher communities and teacher leadership.

- A shared vision and shared leadership practices constituted the school's orientation to improved teacher learning and also showed respect for the contribution of individual staff members.

- Collaboration validated individual practices while it encouraged a collegial focus on shared learning goals.

- Teachers had the authority and ability to influence the processes of the learning teams, while interdependence was developed.

- Collaboration was based on trust to follow the principal, but also on building a mutual trusting relationship between teachers. Trust is considered as the most crucial factor of effective teacher collaboration.

- Support and capacity were built by creating conducive conditions for individual and collective learning.

- Teacher collaboration required a long-term commitment from the principal and staff to maintain its effectiveness.

- Teacher collaboration was contextualised for the particular school.

\section{INVITATIONAL LEADERSHIP}

The principal played a key role in the collaborative structure. The four principles were contextualised as follows:

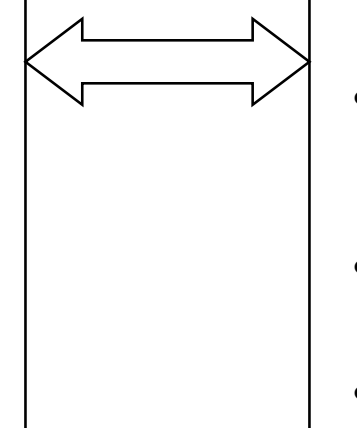

\section{Respect}

- Teachers were seen as masters of their subjects and implemented two curriculums concurrently.

- Opportunities to share their expertise with other schools.

- Viewed himself as cog in big machine.

\section{Trust}

- The principal played a key role in the collaborative structure.

- He removed islands of excellence for staff to share skills/knowledge through various structures.

- A sense of "brotherhood" developed among staff.

\section{Optimism}

- Worth of teachers was affirmed with view of continuous growth.

- The school took initiative to train themselves and others.

\section{$4 \quad$ Intentionality}

- Collaboration does not happen by accident - it has a definite purpose and direction.

- Appropriate structures and ample time were provided for sake of continuity and communication. 


\section{Conclusion}

This study focused on the way in which the principal moved towards a collaborative structure in the school for the sake of the professional development of teachers. It attempted to compare his collaborative efforts with the model of invitational leadership. From these findings it is clear that the implementation of teacher collaboration, although contextualised for the school, was aligned with the four principles of invitational leadership.

Successful teacher collaboration is characterised by a strong leadership presence, and invitational leadership is considered to be the key in designing and sustaining this. The findings in this study showed that the school principal played a key role in providing a supportive school context for teacher collaboration. This implies that once the school principal was committed to encourage effective teacher collaboration, he needed to focus on those factors that could enhance a collaboration culture. This culture was based on mutual respect, trust and care among staff members. By instituting appropriate collaborative structures, the principal communicated confidence in the competence of staff, created ample opportunities and provided time for teacher collaboration to occur at various levels. However, for collaboration to gain momentum initially, the principal had to establish a sense of urgency for teachers to collaborate in addressing their professional challenges and the needs of their students. The various actions of the principal to institute collaboration among the staff showed that he succeeded in abiding by the four principles of invitational leadership too, namely, respect, trust, optimism and intentionality.

With the teaching profession's quest for quality teaching and learning and the pressure of accountability, principals need to recognise and implement professional development models, in particular, collaborative models that have had success in schools. The themes identified in this study provide a tentative theoretical framework to create a better understanding of teacher collaboration and the role that a principal played in its implementation. However, more empirical studies that focus on the developing teacher collaboration in schools by using longitudinal measurements are recommended. Moreover, since school contexts have a powerful effect on teacher collaboration, the leadership styles of principals differ and schools have a unique set of teacher communities, it is important to contextualise teacher collaboration according to each school's particular needs and challenges.

\section{References}


Blacklock, P.J. (2009). The five dimensions of professional learning communities in improving exemplary Texas elementary schools: a descriptive study. Dissertation, Doctor of Education. University of North Texas.

Bowen, S. (2006). Caring, communication and collaboration: A director of teacher development's perspective. In J. Novak, W. Rocca \& A-M. DiBiase (Eds), Creating Inviting Schools (pp.55-70). San Francisco, Ca: Caddo Gap Press.

Burns, G.J. (2007). Invitational leadership in public schools. Doctoral thesis, Faculty of the Graduate School, University of Missouri-Columbia. From https://mospace.umsystem.edu/xmlui/bitstream/handle/10355/4767/research.pdf?sequence $=3$. Retrieved 9 August 2013 .

Brouwer, P. (2011). Collaboration in teams. Doctoral thesis, University of Utrecht.

Brouwer, P., Brekelmans, M., Nieuwenhuis L. \& Simons, R-J. (2012). Community development in the school workplace. International Journal of Educational Management, 26(4), 403-418.

Chappuis, S., Chappuis, J. \& Stiggins, R. (2009). Supporting teacher learning teams. Educational Leadership, 66(5), 56-60.

Christianakis, M. (2010). Collaborative research and teacher education. Issues in Teacher Education, 19(2), 109-125

Cranston, J. (2009, February). Holding the reins of the professional learning community: eight themes from research on principals' perceptions of professional learning communities. Canadian Journal of Educational Administration and Policy, 90, 1-22.

Creswell, J.W. (2007). Qualitative Inquiry and Research Design. Choosing among Five Approaches $\left(2^{\text {nd }}\right.$ ed.) Thousand Oaks, Ca: Sage.

Darling-Hammond, L., Wei, R. C., Andree, A., Richardson, N. \& Orphanos, S. (2009). Professional learning in the learning profession, $p$. A status report on teacher development in the United States and abroad. Dallas, TX: National Staff Development Council. From http://www.nsdc.org/news/NSDCstudy2009.pdf. Accessed 13 February 2012.

Department of Education. (2011). Integrated Strategic Planning Framework for Teacher Education and Development in South Africa. Technical Report: Basic Education and Higher Education and Training. Available at http://getideas.org/resource/integrated$\underline{\text { strategic-planning-framework-teacher-education-and-development-south-af/ Accessed } 16}$ Jan 2013. 
Dymoke, S. \& Harrison, J.K. (2006). Professional development and the beginning teacher: issues of teacher autonomy and institutional conformity in the performance review process. Journal of Education for Teaching, 32(1), 71-92.

Ertesvåg, S.K. (2011). Improving teacher collaboration: The role of classroom characteristics and individual factors on teachers' collaboration. A latent Growth Curve Approach. Paper presented at the ICSEI Congress 2011 International Congress for School effectiveness and Improvement. Linking Research, Policy and Practice to Promote Quality in Education, $\begin{array}{llll}\text { Limassol Cyprus } & \text { January } & \text { th } & \text { From }\end{array}$ http://www.icsei.net/icsei2011/Full\%20Papers/0090.pdf. Accessed 9 January 2013.

Flemming, G.L. (2007). Principals and teachers as continuous learners. In: S.M/ Hord (Ed), Learning Together, Leading Together (pp. 20-30). New York, New York: Teachers College Press.

Fulton, K. \& Britton, T. (2010). STEM teachers in professional learning communities. From http://nctaf.org/wp-content/uploads/2012/01/1098-executive-summary.pdf. Accessed 21 January 2013.

Fulton, K. \& Britton, T. (2011). STEM teachers in professional learning communities: A knowledge synthesis. From http://nctaf.org/wp-content/uploads/2012/01/1098-executivesummary.pdf. Accessed 21 January 2013.

Gaspar, S. (2010). Leadership and the professional learning community. Doctoral thesis. University of Nebraska, Lincoln, NE.

Goddard, Y.L., Goddard, R.D. \& Tschannen-Moran, M. (April 2008). A theoretical and empirical investigation of teacher collaboration for school improvement and student achievement in public elementary schools. Teachers College Record, 109(4), 877-896.

Greer, J.A. (2012). Professional learning and collaboration. Doctoral dissertation. Virginia Polytechnic Institute and State University.

Hargreaves, A. (2007). Sustainable professional learning communities. In L. Stoll \& K.S. Louis (Eds). Professional Learning Communities. Divergence, Depth and Dilemmas (pp.181-193). New York, NY: Open University Press.

Hindin, A., Morocco,C.C., Mott, E.A.\&Aguilar, C.M. (2007). More than just a group: teacher collaboration and learning in the workplace. Teachers and Teaching, Theory and Practice, 13(4), 349-376.

Hunter, M. \& Smith, K.H. (2007). Inviting school success: Invitational education and the art class. Journal of Invitational Practice and Theory, 13, 8-23. 
Johnson, B. \& Christensen, L. (2012). Educational Research. Quantitative, Qualitative, and Mixed Approaches ( $4^{\text {th }}$ ed.). California:Sage.

Katz, S. \& Earl, L. (2010). Learning about networked learning communities. School Effectiveness and School Improvement, 21(1), 27-51.

Lee, H-J. (2004, Fall, 2005, Spring). Developing a professional development programme model based on teachers' needs. The Professional Educator, 27(1 \& 2), 39-49.

Little, J. W. (1982). Norms of collegiality and experimentation: Workplace conditions of school success. American Educational Research Journal, 19(3), 325-346.

Little, J. W. (1990). The persistence of privacy, autonomy and initiative in teachers' professional relations. Teachers' College Record, 91(4), 509-536.

Lockhorst, D., Van der Pol, J. \& Admiraal, W. (2008). A descriptive model of teacher communities. Proceedings of the 6th International Conference on Networked Learning (pp. 253-261). From

http://igitur-archive.library.uu.nl/ivlos/2009-0106-200613/lockhorst\%20\%20a\%20descriptive\%20model.pdf. Accessed 15 January 2013.

Louis, K.S., Dretzke, B. \& Walhstrom, K. (2010). How does leadership affect student achievement? Results from a national US survey. School Effectiveness and School Improvement, 21(3), 315-336.

Maistry, S.M. (2008). Towards collaboration rather than co-operation for effective teacher professional development in South Africa: insights from social practice theory. Southern African Review of Education, 14(1), 119-142.

McLaughlin, M.L. \& Talbert, J.E. (2007). In L. Stoll \& K.S. Louis.Professional Learning Communities. Divergence, Depth and Dilemmas (pp.151-165). New York: Open University Press.

McLaughlin, M.L. \& Talbert, J.E. (2010, Spring). Professional learning communities: Building blocks for school culture and student learning. Voices in Urban Education, 3545. From http://www.stanford.edu/group/suse-crc/cgibin/drupal/sites/default/files/Professional_Learning_Communities.pdf. Accessed 15 January 2013.

National Comprehensive Centre for Teacher Quality. (2011). High-Quality Professional Development for All Teachers: Effectively Allocating Resources, February, Research \& Policy Brief. From http://www.tqsource.org/publications/HighQualityProfessionalDevelopment.pdf. Accessed 13 January 2013. 
Nehring, J. \& Fitzsimons, G. (2011). The professional learning community as subversive activity: countering the culture of conventional schooling. Professional Development in Education, 37(4), 513-535.

Nelson ,T.H., Deuel, A., Slavit, D. \& Kennedy, A. (2010). Leading deep conversations in collaborative inquiry groups. The Clearing House, 83, 175-179,

Nieto, S. 2009. From surviving to thriving. Educational Leadership, 66(5), 89-113.

Novak, J.M. \& DiBiase, A-M. (2006). Sustaining inviting schools. In J. Novak, W. Rocca \& A-M. DiBiase (Eds), Creating Inviting Schools (pp. 249-258). San Francisco, CA: Caddo Gap Press.

Novak, J., Rocca, W.\& DiBiase, A-M. (2006). Creating Inviting Schools. San Francisco, CA: Caddo Gap Press.

Novak, J.M. \& Purkey, W.W. (2001). Invitational Education. Bloomington, In: Phi Delta Kappa Educational Foundation.

Pedder, D. \& Opfer, V.D. (2011). Are we realising the full potential of teachers' professional learning in schools in England? Policy issues and recommendations from a national study. Professional Development in Education, 37(5) 2011, 741-758.

Piccardi, J.M. (2005). Principals' perceptions of factors affecting teacher collaboration in elementary schools. Doctoral dissertation. Rhode Island, Miami:Johnson \& Whales University.

Printy, S. (2010). Principals' influence on instructional quality: insights from US schools. School Leadership and Management, 30(2), 111- 126.

Purkey, W. W, \& Novak, J. M. (2008). Fundamentals of Invitational Education. GA: International Alliance for Invitational Education.

Purkey, W.W.\& Siegel, B. (2003). Becoming an Invitational Leader: A New Approach to Professional and Personal Success. Atlanta: Humanics Trade Group.

Raihani.[AUTHOR: initials? LS] (2008). An Indonesian model of successful school leadership. Journal of Educational Administration, 46(4), 481-496.

Rhodes, C. \& Houghton-Hill, S. (2000). The linkage of continuing professional development and the classroom experience of pupils: barriers perceived by senior managers in some secondary schools. Journal of Inservice Education, 26(3), 423-435.

Richardson, M.A. (2009). Perceptions of principals from high and low performing elementary schools concerning schools as professional learning communities. Doctoral study. Minneapolis, MN: Walden University. 
Sigurðardóttir, A.K. (2010). Professional learning community in relation to school effectiveness. Scandinavian Journal of Educational Research, 54(5), 395-412.

Shaw, D.E., Siegel, B.L. \& Schoelien, A. (2011). Basic tenants of invitational theory and practice (ITP): An invitational glossary. Unpublished document.

Schmidt, J.J. (2004). Diversity and invitational theory and practice. Journal of Invitational Theory and Practice, 10, 26-45.

Steyn, T. (2006). Sustaining an inviting culture in a South African school. A case study. Journal of Educational Studies, 5(1), 1-15.

Steyn, G.M. (2007). Adhering to the assumptions of invitational education. A case study. South African Journal of Education, 27(2), 265-281.

Steyn, G.M. (2009a). Teacher's perceptions of the provision of continuing professional development programmes in South Africa, a qualitative study. Acta Academica, 41(4), 113-137

Steyn, G.M. (2009b). Using reflexive photography to study a principal's perceptions of the impact of professional development on a school, a case study. Koers 74(3), 1-29.

Steyn, G.M. (2010). 'n Skoolhoof se perspektief op professionele ontwikkeling, 'n Enkele gevallestudie ('A school principal's perspective on professional development: A single case study'). Tydskrif vir Geesteswetenskappe, 50(2), 244 -261.

Steyn, G.M. (2012a). 'n Skoolhoof se persepsies van die verwesenliking van Christelike waardes in 'n Suid-Afrikaanse laerskool, 'n Gevallestudie. ('A principal's perceptions of the realisation of Christian values in a South African primary school: A case study') Koers, 77(2), 1-10.

Steyn, G.M. (2012b). Reflections on school leadership focussing on moral and transformational dimensions of a principal's leadership practice. Journal for Christian Scholarship, 48(1\&2), 44-68.

Steyn T. (2013a). Professional and organisational socialisation during leadership succession of a school principal: A narrative inquiry using visual ethnography, South African Journal of Education, 33(2), 315-332.

Steyn. G.M. (2013b). Principal succession. The socialisation of a primary school principal in South Africa. Koers: Bulletin for Christian Scholarship, 78(1), Art. \#426, 9 pages. From http://dx.doi. org/10.4102/koers.v78i1.426

Stoll, L., Bolam, R., Mcmahon, A., Wallace, M. \& Thomas, S. (2006). Professional learning communities: A review of the literature. Journal of Educational Change, 7, 221-258.

Saldaňa, J. (2009). The Coding Manual for Qualitative Researchers. London: Sage. 
Supovitz, J., P. Sirinides, \& H. May. (2010). How principals and peers influence teaching and learning. Educational Administration Quarterly, 46(1), 31-56.

The Centre for Comprehensive School Reform and Improvement. (2009a). Professional learning communities: What is a PLC? From http,

p.//www.centerforcsri.org/plc/literature.html. Accessed 21 January 2013.

The Centre for Comprehensive School Reform and Improvement. (2009b). Professional learning communities: What does the literature and emerging research tell us about the benefits of PLCs? Retrieved from http, p.//www.centerforcsri.org/plc/literature.html. Accessed 21 January 2013.

Vescio, V., Ross, D.\& Adams, A. (2006). A review of research on professional learning communities: What do we know? Paper presented at the NSRF Research Forum January, 2006.

Williams, M.L. (2010). Teacher collaboration as professional development in a large, suburban high school. Unpublished Ph D thesis. Lincoln, Omaha: University of Nebraska. 